\title{
Flavonoid chemistry of Chuquiraga (Asteraceae)
}

\author{
Berta Estela Juárez, María Elena Mendiondo* \\ Facultad Ciencias Naturales e Instituto Miguel Lillo, Universidad Nacional de Tucumán, Fundación \\ Miguel Lillo, CONICET, Miguel Lillo 205/51, (4000) San Miguel de Tucumán, Argentina
}

Received 29 March 2001; accepted 25 June 2001

Keywords: Chuquiraga atacamensis; C. parviflora; C. straminea; Asteraceae; Flavonoids

\section{Subject and source}

Fresh plant material was collected in different Argentine provinces. A voucher of each specimen is deposited at the Herbarium of the Fundación Miguel Lillo (LIL). Chuquiraga atacamensis Kuntze collected in SALTA: Dept. Los Andes (LIL 603627); C. parviflora (Griseb.) Hieron. collected in CATAMARCA, Dept. Andalgalá (LIL 605897); C. straminea Sandwith collected in NEUQUEN, Dept. CollanCura (LIL 605812).

\section{Previous work}

Previous work of flavonoids in other species of Chuquiraga (Bohm and Stuessy, 1995; Mendiondo et al. 1997, 2000; Senatore et al., 1999).

\section{Present study}

Aerial vegetative parts were successively extracted with $80 \% \mathrm{MeOH}, 50 \% \mathrm{MeOH}$ and $\mathrm{MeOH}$. The concentrated extracts were run bidimensionally by $\mathrm{PC}$ on Whatman

* Corresponding author.

E-mail address: bejmem@csnat.unt.edu.ar (M.E. Mendiondo). 
Table 1

Flavonoid distribution in Chuquiraga species $^{\text {a }}$

\begin{tabular}{lccc}
\hline & $\begin{array}{c}\text { Chuquiraga } \\
\text { atacamensis }\end{array}$ & $\begin{array}{c}\text { Chuquiraga } \\
\text { parviflora }\end{array}$ & $\begin{array}{c}\text { Chuquiraga } \\
\text { straminea }\end{array}$ \\
\hline Q-3-Gl & + & & + \\
Q-3-Rut & + & + & + \\
K-3-Gl & + & + & + \\
K-3-Rut & + & + & + \\
K & & + & + \\
Q & & + \\
\hline
\end{tabular}

${ }^{a} \mathrm{Q}-3-\mathrm{Gl}=$ quercetin-3-O-glucoside; Q-3-Rut=quercetin-3-O-rutinoside; K-3-Gl=kaempferol-3-O- glucoside; K-3-Rut=kaempferol-3-O-rutinoside; $\mathrm{K}=$ kaempferol; $\mathrm{Q}=$ quercetin.

3MM, using TBA (tert-butanol-acetic acid-water 3:1:1) and AcOH 15\% (acetic acid $15 \%$ ) as developing solvents. Structures were assigned on the basis of chromatographic behaviour by comparison with authentic samples on TLC (cellulose/acetic acid 40\%; polyamide/chloroform: methanol: butanone: acetylacetone 9:4:2:1), color reactions with NA (Naturstoffereagenz), acid hydrolysis, standard ultraviolet spectrophotometric methods (Mabry et al., 1970; Markham, 1982).

\section{Chemotaxonomic significance}

The results of leaves and flowers flavonoids are presented in Table 1. The flavonoid patterns in the three species of Chuquiraga are similar. Kaempferol, quercetin and their 3-O-glucosides and 3-O-rutinosides were identified. They are comparable with those previously isolated, by us from other argentine species belonging to $\mathrm{Chu}$ quiraga, e.g., Chuquiraga calchaquina, C. longiflora, (Mendiondo et al., 1997); C. avellanedae, C. erinacea, C. erinacea subsp. hystrix, C. incana, C. oppositifolia, $C$. rosulata (Mendiondo et al., 2000). The predominance of these compounds shows the homogeneity of the genus in flavonoid chemistry.

\section{Acknowledgements}

This work was supported in part by a Grant of the Consejo de Investigaciones Universidad Nacional de Tucumán (CIUNT). It was carried out at the Laboratories of the Fundación Miguel Lillo.

\section{References}

Bohm, B.A., Stuessy, T.F., 1995. Sys. Bot. 20, 22.

Mabry, T.J., Markham, K.R., Thomas, M.B., 1970. The Systematic Identification of Flavonoids. Springer Verlag, Heidelberg. 
Markham, K.R., 1982. Techniques of Flavonoid Identification. Academic Press, London. Mendiondo, M.E., Juárez, B.E., Seeligmann, P., 1997. Biochem. Sys. Ecol. 25, 673. Mendiondo, M.E., Juárez, B.E., Seeligmann, P., 2000. Biochem. Sys. Ecol. 28, 283. Senatore, F., Nunziata, A., D’Agostino, M., de Feo, V., 1999. Pharm. Biol. 37, 366. 